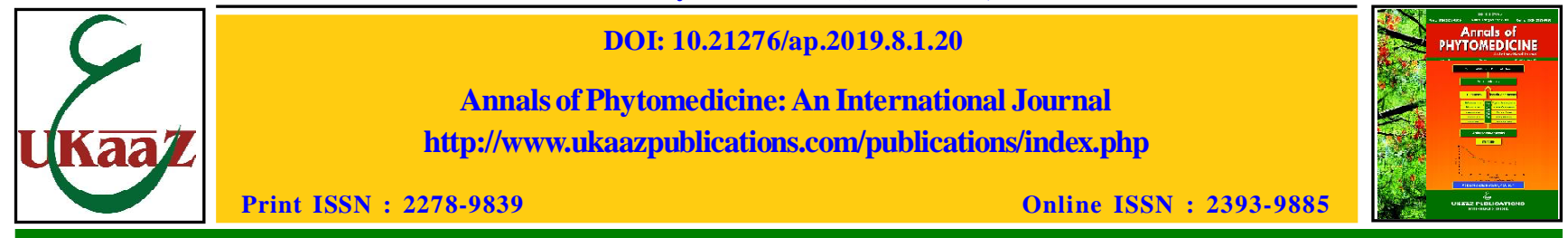

Original article

\title{
Partial purification, immobilization and characterization of amylase produced from Bacillus cereus
}

\author{
Majneesh Chaudhary , Neerja Rana, Devina Vaidya*, Kavita Rana and Arti Ghabru \\ Department of Basic Sciences, Microbiology Division, Dr. Y.S. Parmar University of Horticulture and Forestry, \\ Nauni, Solan-173230, Himachal Pradesh, India \\ *Department of Food Science and Technologgy, Dr. Y.S. Parmar University of Horticulture and Forestry, Nauni, \\ Solan-173230, Himachal Pradesh, India
}

Received April 2, 2019: Revised May 20, 2019: Accepted May 22, 2019: Published online June 30,2019

\begin{abstract}
Amylase is a hydrolytic enzyme that is used widely in industries. It is easier to produce enzymes from bacteria than any other organism. The present work focused on the production of amylase enzyme from bacteria isolated, from hot water spring of Manikaran. The amylase producing bacterial strain screening was performed using starch agar plates. Various biochemical tests were carried out and molecularly; it was identified as Bacillus cereus. Optimum conditions such as temperature, $\mathrm{pH}$ and incubation period were optimized for maximum enzyme production from B. cereus. The optimum $\mathrm{pH}$ was found to be 9.0 and temperature was $45^{\circ} \mathrm{C}$ and $72 \mathrm{~h}$ of incubation period. The enzyme was partially purified by ammonium sulfate precipitation method and it was purified by dialysis. After dialysis, partial purified enzyme was immobilized by entrapment method with sodium alginate as natural matrix. The highest operational stability was six reuses with $54 \%$ relative activity and storage stability up to 35 days with more than $50 \%$ residual activity. The $\mathrm{K}_{\mathrm{m}}$ and $\mathrm{V}_{\max }$ of immobilized enzyme were determined and compared with free enzyme.
\end{abstract}

Keywords: Amylase, ammonium sulphate, dialysis, immobilization, sodium alginate

\section{Introduction}

Amylase (E.C.3.2.1.1) is a hydrolase enzyme that catalyses the hydrolysis of internal $\alpha-1,4$ glycosidic linkages in starch to yield products like glucose and maltose (Sundarram et al., 2014). Among the enzymes, amylases are most widely used industrial enzymes that exhibit great significance, having approximately $65 \%$ of the world enzyme market (Ali et al., 2017). Amylases have attracted global enzyme market due to their vast applications in starch processing, detergent, alcohol, textile, food, paper and pharmaceutical industries (Mageswari et al., 2012; Couto and Sanroman, 2006).

Amylases catalyze hydrolysis of starch into diverse products, namely; dextrin, maltose and smaller polymers containing glucose subunits. Three important categories of amylases are: $\alpha$-amylase, $\alpha$-amylase and glucoamylase. The $\alpha$-amylases (EC 3.2.1.1) are extra cellular enzymes which catalyze random cleavage of the $\alpha-1,4$ glycosidic bonds between adjacent glucose molecules inside the linear amylose chain of starch. The $\alpha$-amylase (EC 3.2.1.2) catalyzes the cleavages of second $\alpha-1,4$ glycosidic bond from the non-reducing end of the chain, resulting in removal of maltose unit. Whereas, glucoamylase (EC 3.2.1.3) catalyzes the hydrolysis of glycosidic bond at $\alpha-1-6$ linkages in addition to $\alpha-1,4$ glycosidic bond from

\footnotetext{
Author for correspondence: Dr. Majneesh Chaudhary
}

Professor, Department of Basic Sciences, Microbiology Division, Dr YS Parmar University of Horticulture and Forestry, Nauni, Solan173230, Himachal Pradesh, India

E-mail: majneeshchaudhary3003@gmail.com

Tel.: +91-8219929881

Copyright $($ ) 2019 Ukaaz Publications. All rights reserved.

Email: ukaaz@yahoo.com; Website: www.ukaazpublications.com non-reducing ends of amylose and amylopectin of starch molecules (Anto et al., 2006).

The industrial application of enzymes is also hampered due to lack of reusability, availability and limited stability under operational conditions. In food industries, amylase enzymes are utilized in baking, brewing, preparation of digestive aids, preparation of cakes, fruit juices and starch syrups (Rana et al., 2017). The use of enzymes in a free form is very uneconomical because the enzymes generally cannot be recovered at the end of the reaction. These drawbacks can be overcome by immobilization of the enzyme, thereby rendering it more stable and easy to recover and recycle. It is a very effective alternative for gripping the problems of instability, repetitive use and reduction in the cost of enzyme. Immobilization increases shelf-life of enzyme and enhances enzyme and its activity over broader $\mathrm{pH}$ and temperature range. For immobilization, one of the most frequently used methods is entrapment of enzyme within porous matrices in the form of beads (Dey et al., 2003). This sort of system is safe, simple, cheap and contribute to good mechanical strength with high porosity for substrate. Thus, potential of thermostable enzymes from bacteria inhabiting hot water springs of Himachal Pradesh can be exploited in food industries (Meenakshi et al., 2018).

\section{Materials and Methods}

\subsection{Isolation and identification of amylase producing} microorganisms from hot water springs

Isolation of amylase producing bacterial isolates were carried out in the lab of Microbiology section, Department of Basic Sciences, 
Dr Y. S. Parmar University of Horticulture and Forestry, Nauni, Solan (H.P) from hot water spring of Manikaran of Kullu district of Himachal Pradesh. Screening of amylase producing bacterial isolates was done on the basis of qualitative (Shaw et al.,1995) and quantitative assay. For the identification of MW6, morphological, biochemical and molecular characterization by $16 \mathrm{~S}$ rDNA sequence analysis was done as per method of Sambrook et al. (1989)

\subsection{Partial purification of amylase}

The cell free crude extracts of the enzyme were subjected to sequential ammonium sulphate saturations as per method of Hamilton et al. (1999). Different concentrations of ammonium sulphate in the range of 0-80\% were evaluated to attain saturation point. The crude enzyme was treated with solid ammonium sulphate with continuous stirring on magnetic stirrer and separates into saturation ranges $0-20 \%, 20-40 \%, 40-60 \%$ and $60-80 \%$. The precipitates collected by centrifugation $(10,000 \mathrm{~g}$ for $15 \mathrm{~min})$ were dissolved in $0.1 \mathrm{M}$ phosphate buffer $(\mathrm{pH} 7.0)$. The dialysis was carried out to remove the traces of ammonium sulphate. The pooled ammonium sulphate fractionations, which were dissolved in $0.1 \mathrm{M}$ phosphate buffer ( $\mathrm{pH} \mathrm{7)}$ and were introduced inside a dialysis membrane and kept in beaker filled with the same buffer for $24 \mathrm{~h}$ at $4^{\circ} \mathrm{C}$. Thereafter, enzymes activity and protein content were estimated. The dialyzed concentrated enzyme was kept at $4^{\circ} \mathrm{C}$ for further application.

\subsection{Immobilization of purified amylase}

Immobilization of purified amylase was done by the entrapment method in sodium alginate as per method given by Rajagopalan and Krishnan (2008). In this method, 0.5, 1.0, 1.5, 2, 2.5 or 3\% solutions of sodium alginate were prepared in $0.1 \mathrm{M}$ phosphate buffer $(\mathrm{pH}$ 7.0). After cooling down to room temperature, $1 \mathrm{ml}$ of enzyme stock solution was mixed with $9 \mathrm{ml}$ of sodium alginate solution. The mixture was then suspended drop wise into prechilled $0.1,0.2$, $0.3,0.4$ or $0.5 \mathrm{M}$ calcium chloride solution with gentle stirring at $4^{\circ} \mathrm{C}$ for $2 \mathrm{~h}$. The formed beads were recovered by filtration and thoroughly washed with distilled water. These beads were then stored in $0.1 \mathrm{M}$ phosphate buffer $(\mathrm{pH} 7.0)$ at $4{ }^{\circ} \mathrm{C}$. The filtered calcium chloride solution was collected for enzyme activity determination.

\section{Results}

The studies were conducted to produce and evaluate amylase enzyme from bacteria inhabiting hot water spring of Himachal Pradesh. The amylase produced from B. cereus was partial purified, immobilized and characterized for further studies. The results of present study are presented and discussed under different headings as :

\subsection{Isolation and identification of amylase producing bacteria}

Out of 27 isolates, 8 were found to be the amylase producers with clear zones of starch hydrolysis with varying diameters. The isolates MW6, i.e., B. cereus from the hot spring exhibited highest zone size of $7.23 \mathrm{~mm}$ with enzyme index of 24.62 and having amylase activity of $73.75 \mathrm{IU}$ and protein content $24.11 \mathrm{mg} / \mathrm{ml}$ with specific activity of $3.05 \mathrm{IU} / \mathrm{mg}$. On the basis of morphological and biochemical characteristics, the MW6 isolate was identified as per the criteria of Bergey's Manual of Systematic Bacteriology (Table 1).

Table1: Morphological and biochemical characterization

\begin{tabular}{|c|c|}
\hline Characteristics & MW6 \\
\hline \multicolumn{2}{|c|}{ Morphological } \\
\hline Form & Circular \\
\hline Elevation & Raised \\
\hline Margin & Entire \\
\hline Color & Creamish \\
\hline Gram's reaction & + \\
\hline Shape & Rod \\
\hline Endospore formation & - \\
\hline Motility & + \\
\hline Capsule formation & - \\
\hline \multicolumn{2}{|c|}{ Biochemical } \\
\hline Oxidase test & + \\
\hline Catalase test & - \\
\hline Indole test & - \\
\hline Methyl red test & - \\
\hline Voges Proskauer test & + \\
\hline $\mathrm{H}_{2} \mathrm{~S}$ test & - \\
\hline Simmon citrate test & - \\
\hline Glucose test & + \\
\hline Sucrose test & - \\
\hline Lactose test & - \\
\hline Urease test & - \\
\hline
\end{tabular}

Molecular identification of the isolate MW6 was done by sequencing part of the 16S ribosomal DNA (16S rDNA). The amplification of $16 \mathrm{~S}$ rDNA was confirmed by agarose gel electrophoresis. The PCR product was gel eluted and sequenced (Figure1). The BLASTn sequencing of MW6 sequence revealed the presence of bacteria belonging to genus Bacillus spp. showing $99 \%$ similarity with their nearest relatives in the NCBI GenBank database. Therefore, from the results, it was evident that isolates MW6 clustered closely with B. cereus strain VBE08 (MG027652). Hence, the strains MW6 identified as B. cereus.

\subsection{Partial purification of amylase produced from $B$. cereus}

The crude extract of B. cereus contained $9.56 \mathrm{mg} / \mathrm{ml}$ protein content with specific activity of $30.55 \mathrm{IU} / \mathrm{mg}$. The isolate got precipitated with $0-80 \%$ ammonium sulphate with increased specific activity to $41.56 \mathrm{IU} / \mathrm{mg}$. The fold purification was increased to 1.36 with $69.99 \%$ purification (Table 2). It was found that the dialysis further concentrated the amylase with specific activity of $54.85 \mathrm{IU} / \mathrm{mg}$ with 1.79 fold of purification. 


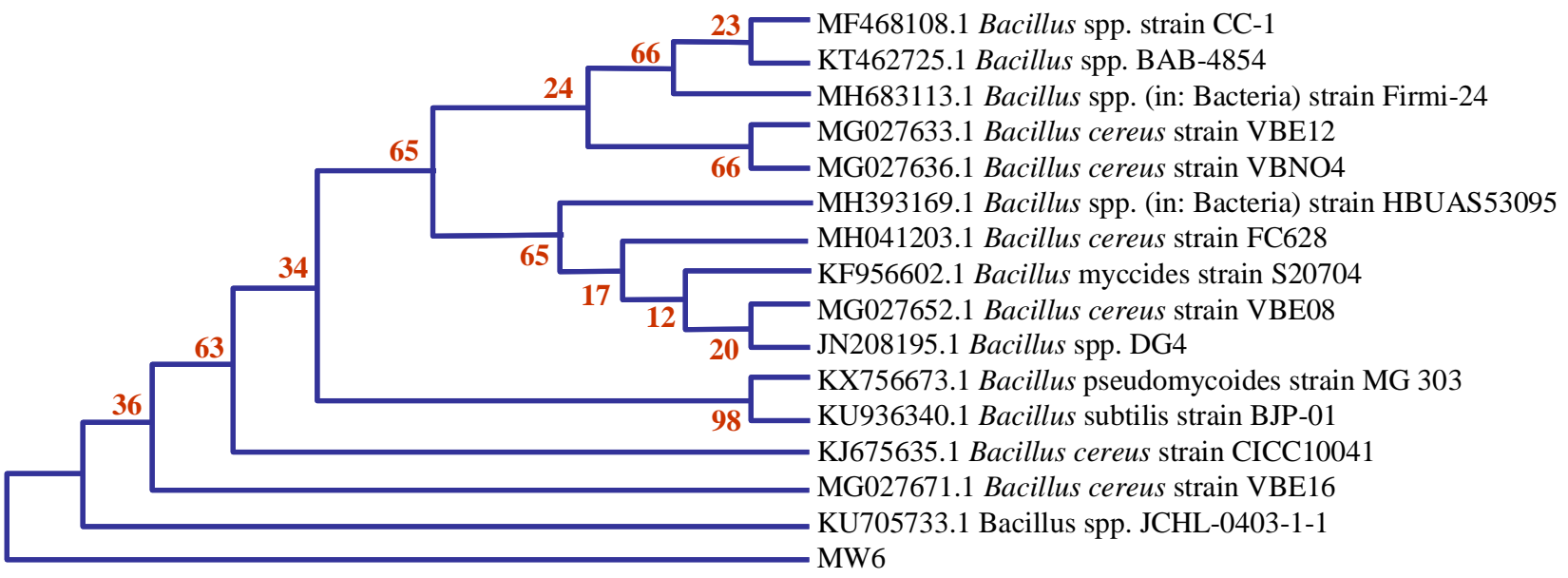

Figure 1: Neighbour joining tree based on 16S rDNA sequences showing the phylogenetic relationship of bacterial isolates MW6 with the analyzed sequences.

Table 2: Partial purification summary of amylase from bacterial isolate B. cereus

\begin{tabular}{|l|c|c|c|c|c|}
\hline $\begin{array}{l}\text { Purification } \\
\text { step }\end{array}$ & $\begin{array}{c}\text { Total amylase } \\
\text { activity(IU) }\end{array}$ & $\begin{array}{c}\text { Protein } \\
\text { content (m/ml) }\end{array}$ & $\begin{array}{c}\text { Specific } \\
\text { activity (IU/mg) }\end{array}$ & $\begin{array}{c}\text { Fold } \\
\text { purification }\end{array}$ & $\begin{array}{c}\text { Percent } \\
\text { purification (\%) }\end{array}$ \\
\hline Crude enzyme & 292.15 & 9.56 & 30.55 & 1.00 & 100 \\
$\begin{array}{l}\text { Ammonium sulphate fractionation } \\
(0-80 \%)\end{array}$ & 204.49 & 4.92 & 41.56 & 1.36 & 69.99 \\
Dialysis & 194.73 & 3.55 & 54.85 & 1.79 & 66.65 \\
\hline
\end{tabular}

Total activity: Enzyme activity in given volume (IU)

Protein content: $\mathrm{mg} / \mathrm{ml}$

Specific activity: Enzyme activity per unit protein concentration (IU/mg)

Purification fold: Increase in specific activity

Percent purification: Remaining amylase activity as \% of the initial amylase activity

\subsection{Immobilization of partial purified amylase from B. cereus}

The amylase was immobilized by entrapment in natural polymer, i.e., sodium alginate. The data presented in Table 3 and Plate 1 showed that immobilization of amylase with $3 \%$ concentration of sodium alginate gave highest yield of $67.39 \%$ for B. cereus. The data showed that immobilized enzyme gave the activity of 59.76 $\mathrm{IU} / \mathrm{g}$. With the increase in concentration of sodium alginate, there was increase in the immobilization yield. However, the reduction in yield was noticed beyond $3.0 \%$. It was also found that at $1.0 \%$ sodium alginate, no beads were formed. Several workers have used calcium alginate for immobilization of enzymes.

Table 3: Effect of sodium alginate concentration on the amylase activity and immobilization yield and plate 1 represent immobilized enzyme

\begin{tabular}{|c|c|c|}
\hline $\begin{array}{c}\text { Concentration of } \\
\text { sodium alginate (\%) }\end{array}$ & $\begin{array}{c}\text { Amylase activity of } \\
\text { immobilized enzyme } \\
\text { (IU/g) }\end{array}$ & $\begin{array}{c}\text { Immobilization yield } \\
\text { (\%) }\end{array}$ \\
\hline 1.0 & No beads & - \\
\hline 2.0 & 51.78 & $55.77(48.29)$ \\
\hline 3.0 & 59.76 & $67.39(55.15)$ \\
\hline 4.0 & 44.89 & $48.35(44.03)$ \\
\hline C.D 0.05 & 1.83 & 1.07 \\
\hline
\end{tabular}

Amylase activity of free enzyme B. cereus (194.73IU)

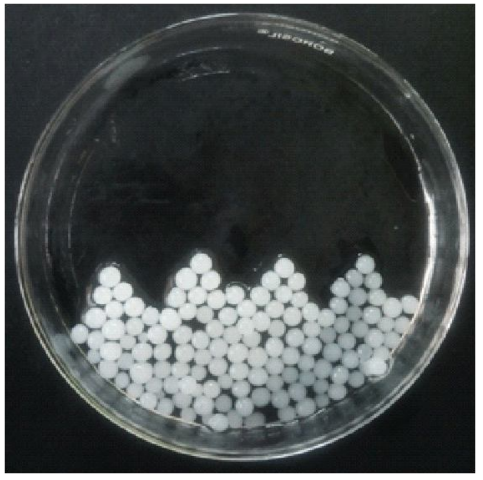

Plate 1: Immobilized enzyme 


\subsection{Operational stability of immobilized amylase}

The operational stability of amylase entrapped in sodium alginate and amylase activity was assessed by reusing the immobilized enzyme up to six cycles. The data indicated that alginate entrapped enzyme was stable up to third cycles with minimum loss in activity for both the isolates. After $3^{\text {rd }}$ cycle, the bound enzymes had leached from the beads and the relative activity started declining. The relative activity after $6^{\text {th }}$ cycle reached to $64.63 \%$ (Figure 2).

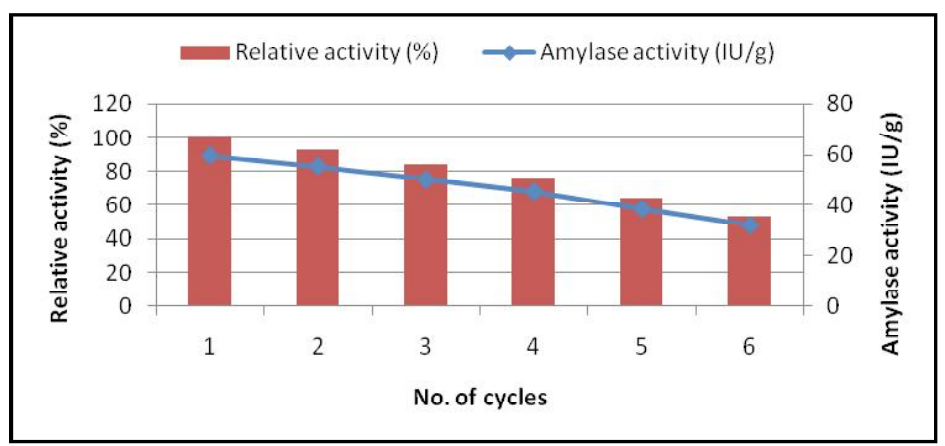

Figure 2: Operational stability of immobilized amylase isolated from B. cereus.

\subsection{Storage stability of immobilized amylase}

The storage stability of the immobilized amylase was examined for 35 days storage in the phosphate buffer, $\mathrm{pH} 7$ at $4{ }^{\circ} \mathrm{C}$ at interval of 7 days. The data revealed that the alginate entrapped enzyme stored at $4^{\circ} \mathrm{C}$ was stable up to 14 days with relative activity of $85.95 \%$. However, the entrapped enzyme started losing activity after 7 days and more than $50 \%$ activity was reduced after 35 days of storage.

\subsection{Kinetic measurement of free and immobilized enzyme}

The $\mathrm{K}_{\mathrm{m}}$ and $\mathrm{V}_{\text {max }}$ values of $\alpha$-amylase were determined by using Line weaver-Burk double reciprocal plot. The reciprocal of reaction velocity, i.e., $1 / \mathrm{V}$ was plotted against the reciprocal of the substrate (starch) concentration, i.e., 1/[S] (Figyres 3 and 4). The $\mathrm{K}_{\mathrm{m}}$ and $\mathrm{V}_{\max }$ value of free enzyme and immobilized enzyme for $B$. cereus were 1.0 and $1.25 \mathrm{mg} / \mathrm{ml}$ and 41.66 and $38.46 \mathrm{IU} / \mathrm{ml}$, respectively (Table 4).

Table 4: Kinetic measurement of free and immobilized enzyme isolated from B. cereus

\begin{tabular}{|l|c|c|}
\hline Enzyme form & $\mathbf{K}_{\mathbf{m}}(\mathbf{m g} / \mathbf{m l})$ & $\mathbf{V}_{\max }(\mathbf{U} / \mathbf{m l})$ \\
\hline Free & 1.0 & 41.66 \\
Immobilized enzyme & 1.25 & 38.46 \\
\hline
\end{tabular}

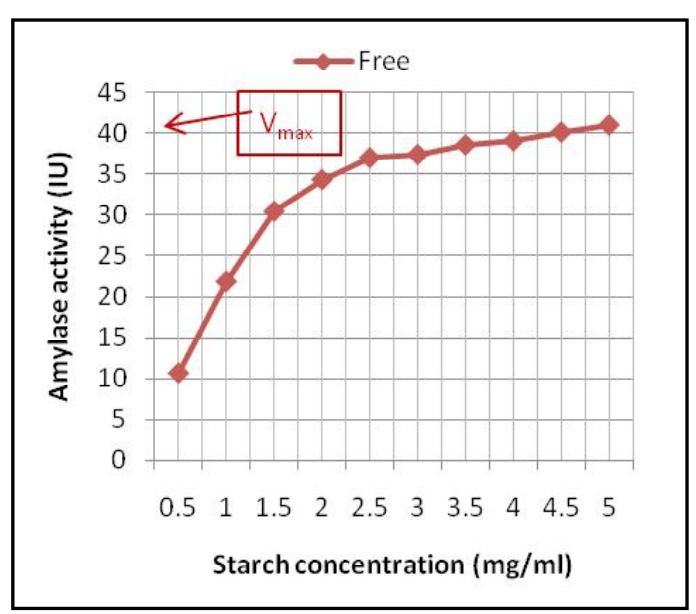

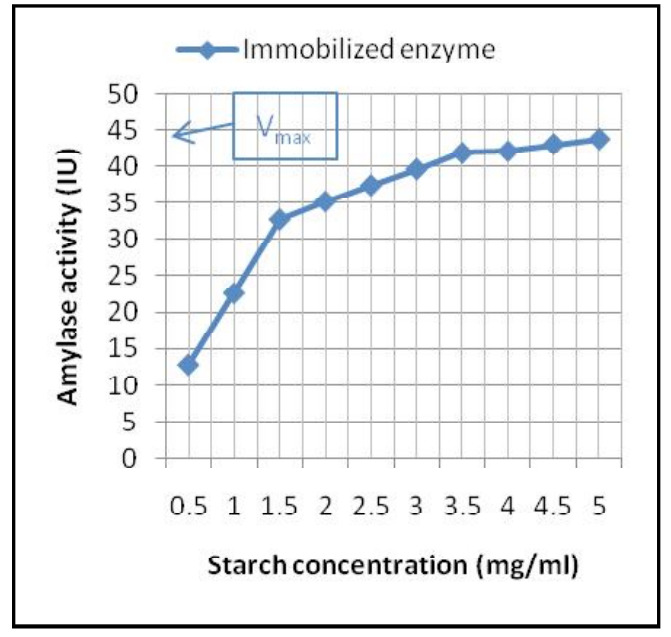

Figure 3: Michaelis-Menten direct fit for the free and immobilized enzyme for B. cereus.

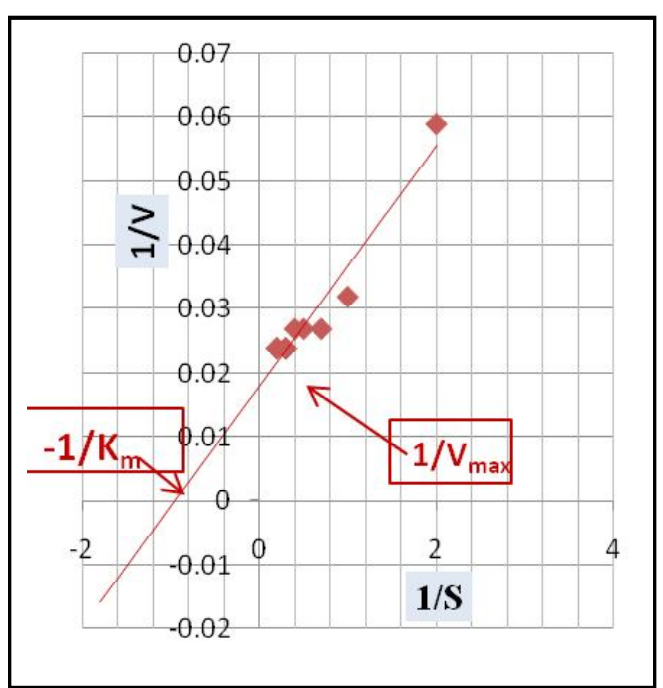




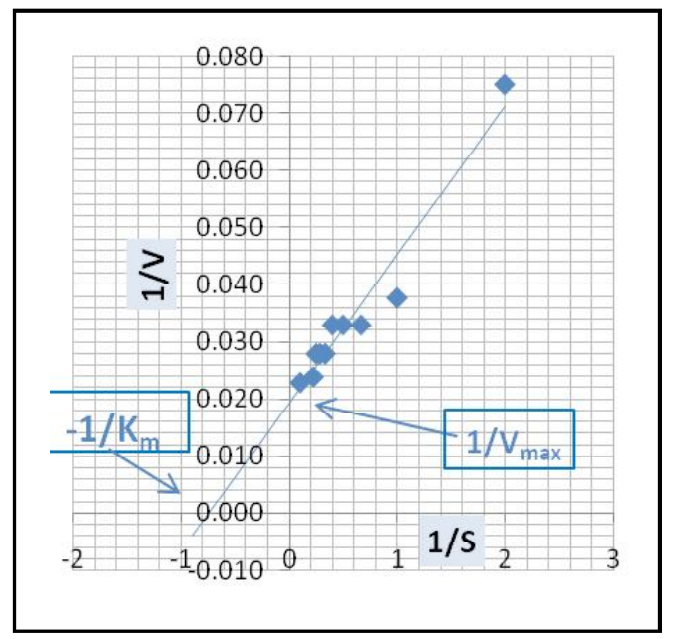

Figure 4: Line weaver- Burk double reciprocal plot of $1 / \mathrm{V}$ versus $1 / \mathrm{S}$ for the free and immobilized enzyme for $B$. cereus.

\section{Discussion}

Many microorganisms especially several species belonging to Bacillus are known to produce variety of enzymes and they have a wide range of industrial applications. Of these enzymes, amylases are of particular significance to industry. The present study has reported isolation and identification of amylase producing bacteria. The isolate MW6 exhibited higher amylase activity and identified as $B$. cereus. Nithya et al. (2016) reported that an isolate KSU-6 showed maximum amylase activity of $37.52 \mathrm{U} \mathrm{ml}^{-1}$. Rana et al. (2017a) also reported that highest amylase activity of $61.35 \mathrm{IU}$ was obtained in apple pomace as a low cost substrate at a temperature of $45^{\circ} \mathrm{C}$, pH 9.0 and incubation period of $72 \mathrm{~h}$. Similar morphological and biochemical characteristics have been reported by Kirti et al. (2016). Similar result of molecular based identification was highlighted by Rana et al. (2017a). The amylase producing bacterial isolate $\mathrm{J} 2$ by $16 \mathrm{~S}$ rDNA sequencing revealed the strain identify as Bacillus thuringiensis J2 (KY990713).

Most of bacterial and fungal amylases were precipitated with $80 \%$ saturation of ammonium sulphate. Ammonium sulphate is the strongest precipitant, since it is highly soluble in water, cheap and has no deleterious effect on the structure of protein. In this study, enzyme was purified by ammonium sulphate fractionation $(0-80 \%)$. The specific activity of the purified enzyme was $41.56 \mathrm{IU} / \mathrm{mg}$ with 1.36 folds of purification. Bukhari and Rehman (2015) purified Bacillus subtilis with ammonium sulphate precipitation (80\%) and the purified amylase could be detected as a single band of $59 \mathrm{kDa}$ by SDS polyacrylamide gel electrophoresis. Kohli et al. (2016) also purified enzyme with $75 \%$ ammonium sulphate with 21 fold of purification. El-Kady et al. (2017) isolated and purified thermophilic Bacillus spp. NRC12017. They purified alpha amylase by $60-80 \%$ ammonium sulphate precipitation.

Alginate is the one of supporting matrix that can be used for immobilization of enzyme. The main advantages of this matrix are non-toxic, high stability, high porosity, simple procedure for immobilization and relatively cheap (Anwar et al., 2009). Pore size of the beads should be such that substrate and product can easily diffuse in and out of the alginate gel matrix but the enzyme should retain in the microenvironment of beads (Riaz et al., 2009).
Dey et al. (2003) found $4.0 \%$ sodium alginate as the best concentration for efficient immobilization of $\alpha$-amylase produced by B.circulans. Dey et al. (2015) reported highest amylase activity at $4.0 \%$ concentration of sodium alginate. Decrease in the immobilization yield at lower concentration of alginate is due to the larger pore size and consequently greater leakage of the enzyme from matrix and at higher concentration, there is decrease in porosity of gel beads, which caused diffusion limitation of the substrate. The most important application of immobilized enzyme is in its practical utility for commercial purpose and their repeated use as they remain separated from the products and reactants. The our alginate entrapped enzyme was reusable up to 6 cycles with relative activity of $64.63 \%$. Demirkan et al. (2011) reported 6 reuses of calcium alginate entrapped $B$. amyloliquefaciens $\alpha$-amylase with $51 \%$ residual activity. Talekar and Chavare (2012) reported 10 reuses of calcium alginate immobilized amylase with $35 \%$ residual activity. Riaz et al. (2015) isolated Bacillus licheniformis AR-1 producing alpha amylase and immobilized the enzyme on calciumalginate beads. They reported that calcium-alginate entrapped enzyme can be reused up to 4 cycles. Zusfahair et al. (2017b) immobilized amylase of Bacillus thuringiens is in chitosan and used up to five times with the remaining activity of $43.3 \%$.

Storage stability is one of the most important parameters to be considered in enzyme immobilization. In general, if an enzyme is in a solution, it is not stable during storage which makes the immobilized enzyme more advantageous than that of the free one (Keerti et al., 2014). In our study, the entrapped enzyme started losing activity after 7 days and more than $50 \%$ activity was reduced after 35 days of storage at $4^{\circ} \mathrm{C}$. Andriani et al. (2012) reported a loss of $90 \%$ of activity for cellulase from $B$. subtillis in the alginate after 12 days. The extended stability observed in the immobilized pectinase in alginate is due to a protective microenvironment provided by alginate that gives a stabilization effect, thus minimizing possible distortion effects which might be imposed by an aqueous medium on the active site of the immobilized enzyme (Yahsi et al., 2005). Bindu and Mahanan (2017) studied the storage stability of immobilized enzyme and reported that the stability was $64.5 \%$ of its initial activity after six months.

It is difficult to compare the kinetic values of $\alpha$-amylase obtained by other researchers in view of the usage of different starch concentrations and different assay conditions. The immobilized $\alpha$-amylase showed higher $\mathrm{K}_{\mathrm{m}}$ value than that of the free enzyme because of the $\alpha$-amylase concentration gradient that is established from the bulk of the solution to the immobilized form within the support. Therefore, the substrate saturation of the immobilized enzyme requires a higher concentration of $\alpha$-amylase in solution. In general, $\mathrm{K}_{\mathrm{m}}$ value of an immobilized enzyme is higher than that of free enzyme due to less availability of the substrate to the active sites of enzyme due to chemical bonding, diffusion limitation, and confinement of the enzyme molecules within the polymeric support. The change in the affinity for its substrate is also caused by structural changes in the enzyme introduced by the immobilization procedure and lower accessibility of the substrates to the active site of the immobilized enzyme (Arica et al., 2004). In the present results, the $\mathrm{V}_{\max }$ value decreased moderately after immobilization, which indicates that the immobilization procedure and the matrix did not markedly alter the microenvironment of the enzyme molecule. Zusfahair et al. (2017a) reported the $\mathrm{K}_{\mathrm{m}}(0.3 \mathrm{mM}$ and $0.12 \mathrm{mM})$ 
and $\mathrm{V}_{\text {max }}(105.3 \mathrm{U} / \mathrm{ml}$ and $10.1 \mathrm{U} / \mathrm{ml})$ values of free and immobilized amylases, respectively. Bindu and Mohann (2017) studied the kinetic measurements of free and immobilized amylase and reported similar results. They reported higher $\mathrm{K}_{\mathrm{m}}$ value for immobilized amylase $(0.58 \mathrm{mg} / \mathrm{ml})$ than the free enzyme $(0.45 \mathrm{mg} / \mathrm{ml})$. They also reported slightly lower value of $\mathrm{V}_{\max }(24.39 \mathrm{umol} / \mathrm{mg} / \mathrm{min})$ for immobilized enzyme than the free enzyme (34.38 umol/mg/min).

\section{Conclusion}

It was concluded that the bacterial isolate, i.e., MW6 isolated from hot water spring of Manikaran (Kullu) in Himachal Pradesh were found to be best sources for amylase production. The crude amylase was partially purified with ammonium sulphate fractionation (0$80 \%$ ) to 1.79 folds with $66.65 \%$ recovery. The amylase was immobilized by entrapment method on natural matrices, i.e., sodium alginate with $64.37 \%$ immobilized yield. The enzyme entrapped in alginate can be reused up to six times with relative activity of $53.68 \%$ and was found stable up to 35 days with more than $50 \%$ relative activity. On the basis of reusability and storage stability, entrapment of enzyme in alginate matrix was found to be the best. Amylase immobilized in alginate matrix was best matrix as it slightly altered the $\mathrm{V}_{\max }$ value and yielded high amylase activity and immobilization yield. On the basis of immobilize amylase yield, properties and stability, it can be concluded that the microbial amylase from hot water spring of Manikaran (Kullu) of Himachal Pradesh has a potential to be explored in industries.

\section{Conflict of interest}

The authors declare that no conflict of interest exists in the course of conducting this research. All authors had final decision regarding the manuscript and the decision to submit the findings for publication.

\section{References}

Ali, E.H.; El-Nagdy, M.A.; Al-Garni, S.M.; Ahmed, M.S and Rawaa, A.M. (2017) Enhancement of alpha amylase production by Aspergillus flavus AUMC 11685 on mandarin (Citrus reticulata) peel using submerged fermentation. Eur. J. Biol. Res.,7:154-164.

Andriani, D.; Sunwoo, C.; Ryu, H. W.; Prasetya, B. and Park, D. H. (2012). Immobilization of cellulase from newly isolated strain Bacillus subtilis TD6 using calcium alginate as a support material. Bioprocess Biosyst. Eng., 35:29-33.

Anto, H,; Trivedi, U. and Patel, K. (2006). Alpha amylase production by Bacillus cereus MTCC1305 using solid-state fermentation. Food Technol. Biotech., 44:241-245.

Anwar, A.; Qader, S. A. U.; Raiz, A.; Iqbal, S. and Azhar, A. (2009). Calcium alginate: A support material for immobilization of proteases from newly isolated strain of Bacillus subtilis KIBGEHAS. World Appl. Sci. J., 7:1281-1286.

Arica, Y.; Bayramogflu, G. and Yilmaz, M. (2004). Immobilization of a thermostable $\alpha$-amylase onto reactive membranes: Kinetics characterization and application to continuous starch hydrolysis. Food Chem., 84:591-599.

Bindu, V. V. and Mahanan, P. V. (2017). Enhanced stability of $\alpha$-amylase via immobilization onto chitosan- $\mathrm{TiO}_{2}$ Nanocomposite. Nanosci. Nanotechnol., 4:1-9.

Bukhari, D. A. and Rehman, A. (2015). Purification and characterization of $\alpha$-amylase from Bacillus subtilis isolated from local environment. Pak. J. Zool., 47:905-911.
Couto, S. R. and Sanroman, M. A. (2006). Application of solid state fermentation to food industry: A review. Int. J. Food. Eng.,76:291302 .

Demirkan, E.; Dincbas, S.; Sevinc, N. and Ertan, F. (2011). Immobilization of B. amyloliquefaciens $\alpha$-amylase and comparison of some of its enzymatic properties with the free form. Rom. Biotechnol. Lett., 16:6690-6701.

Dey, A.; Maiti, T. K. and Roy, P. (2015). Improvement of the enzymatic performance of lipase from Pseudomonas sp. ADT3 via entrapment in alginate hydrogel beads. Int. J. Sci. Res., 5:22503153.

Dey, G.; Singh, B. and Banerjee, R. (2003). Immobilization of $\alpha$-amylase produced by Bacillus circulans GRS313. Braz. Arch. Biol. Technol., 46:167-176.

El-Kady, E. M.; Asker, M. S.; Hassanein, S. M.; Elmansy, E.A. and El-Beih, F. M. (2017). Optimization, production and partial purification of thermostable $\alpha$-amylase produced by marine bacterium Bacillus sp. NRC12017. Asian. J. Pharm. Clin. Res., 9:558-570.

Hamilton, L. M.; Kelly, C. T. and Fogarty, W. M. (1999). Production and properties of the raw starch-digesting $\alpha$-amylase of Bacillus sp. IMD 435. Process Biochem., 35:27-31.

Keerti.; Gupta, A.; Kumar, V.; Dubey, A. and Verma, A. K. (2014). Kinetic characterization and effect of immobilized thermostable $\alpha$ glucosidase in alginate gel beads on sugarcane juice. Hindawi Publishing Corporation, 14:1-8.

Kirti, S.; Dipta, B.; Bhardwaj, S.; Pawar, R. and Kaushal, R. (2016). Screening and characterization of plant growth promoting rhizobacteria associated with cherry (Prunu savium L.). The Bioscan., 11(4): 2111-2115.

Kohli, I.; Tulli, R. and Singh, V. P. (2016). Purification and characterization of maltose forming thermostable alkaline $\alpha$-amylase from Bacillus gibsonii S213. Int. J. Adv. Res., 4:356-366.

Mageswari, A.; Subramanian, P.; Chandrasekaran, S.; Sivashanmugam, K.; Babu, S and Gothandam, K. M. (2012). Optimization and immobilization of amylase obtained from halotolerant bacteria isolated from solar salterns. Genet. Eng. Biotechnol. J., 10:201-208.

Meenakshi Rana, N. and Chauhan, A. (2018). Extraction and characterization of biocolors from bacterial isolates of Pseudomonas sp. M1 and MS2. Ann. Phytomed.,7(1):63-68.

Nithya, K.; Muthukumar, C.; Dhanasekaran, D.; Kadaikunnan, S.; Alharbi, N. S.; Khaled, J. M. and Thajuddun, N. (2016). Production, optimization and partial characterisation of thermostable and alkaline amylase from Bacillus licheniformis KSU-6. Int. J. Agric. Biol., 18:1188-1194.

Rajagopalan, G. and Krishnan, C. (2008). Immobilization of malto oligosac charide forming $\alpha$-amylase from $B$. subtilis KCC103: Properties and application in starch hydrolysis. J.Chem Technol. Biot., 83:1511-1517.

Rana, N.; Verma, N.; Vaidya, D. and Dipta, B. (2017). Application of amylase producing bacteria isolated from hot spring water in food industry. Ann. Phytomed., 6(2):93-100.

Rana, N.; Verma, N.; Vaidya, D. and Dipta, B. (2017a). Production of amylase from Bacillus thuringiensis $\mathrm{J} 2$ using apple pomace as substrate in solid state fermentation. Curr. Microbiol., 6:3465-3474.

Riaz,A.; Ansari, B; Siddiqui,A.; Ahmed, S.; Naheed, S. and Qader, S.A. U. (2015). Immobilization of $\alpha$-amylase in operationally stable calciumalginate beads: A cost effective technique for enzyme aided industrial processes. J. Biotechnol. Biochem., 3:81-86. 
Riaz, Q. S. A. U.; Anwar, A. and Iqbal, S. (2009). Immobilization of a thermostable $\alpha$-amylase on calcium alginate beads from Bacillus subtilis KIBGE-HAR. Aust. J. Basic Appl. Sci., 3:2883-2887.

Sambrook, J.; Fritsch, E. F. and Maniatis, T. (1989). Molecular cloning: A laboratory manual. New York: Cold Spring Harbor Laboratory. pp: 162

Shaw, J. F.; Lin, F. P.; Chen, S. and Chen, H. C. (1995). Botanical Bulletin Academia Sinica, 36:195-200.

Sundarram, A. and Murthy, T.P.K. (2014). $\alpha$-amylase production and applications: A review. J. Appl. Environ.Microbiol., 2:166-175.
Talekar, S. and Chavare, S. (2012). Optimization of immobilization of $\alpha$ amylase in alginate gel and its comparative biochemical studies with free $\alpha$-amylase. Res. Sci. Technol., 4:1-5.

Yahsi, A.;Sahin, F.;Demirel, G. and Tumturk, H. (2005). Binary immobilization of tyrosinase by using gel beads and poly (acrylamide-co-acrylic acid) hydrogels. Int. J. Biol. Macromol., 36:253-258.

Zusfahair Ningsih, D. R.; Kartika, D.; Fatoni, A. and Zuliana, A. L. (2017b). Bacillus thuringiensis HCB6 amylase immobilization by chitosan beads. IOP Conference Series Materials Mater. Sci. Eng. C., 172:1-6.

Zusfahair Ningsih, D.R.; Kartika, D.;Fatoni, A. and Permatawati, I. (2017a). Immobilization and characterization of Bacillus thuringiensis HCB6 amylase in calcium alginate matrix Molekul.,12:70-77.

Citation: Majneesh Chaudhary, Neerja Rana, Devina Vaidya, Kavita Rana and Arti Ghabru (2019). Partial purification, immobilization and characterization of amylase produced from Bacillus cereus. Ann. Phytomed., 8(1):153-159. 